\title{
THE ENFORCEMENT OF CHILD LABOR LEGISLATION IN ILLINOIS
}

\author{
By Hon. Edgar T. Davies, \\ Chief Factory Inspector of Illinois.
}

Modern industrialism has produced modern individualism. It has developed a parenthood that is prone to raise children as human commodities for the factory, the mills, the mines and other places where avenues of employment are ever open to children. The result has been the growth of a child labor evil that is the shame of modern civilization. It has been fostered through three agencies-the employer; the commercialism of parenthood; and a lack of uniformity of legislation, restricting the employment of children under fourteen years of age, and regulating the employment of children between the ages of fourteen and sixteen. Lack of enforced laws in some states and lax methods of factory inspection in others have contributed in a measure to the result. There are states in which there have not been sufficient appropriations along with legislation; while in others the responsibility for the enforcement of laws has not been properly defined, and laws cannot enforce themselves.

In some localities child labor laws are not supplemented by adequate compulsory education laws, and in many states the age limit is too low, and there is not sufficient educational test. Possibly the curriculum of our public schools should be expanded to include the utilitarian as well as the educative, and to expand manual training that would educate the hand as well as the head. The inclination of most boys is for the manual as well as the academic. Some states do not protect children engaged in hazardous employment. All of these defects tend to a great social waste during that period of childhood that is most precious to the building up of the mind and muscle of future citizenship.

The question of child labor has become a source of such national apprehension that Senator Beveridge advocates a bill aimed at those 
industries that encourage it. The question is one, however, that cannot be settled solely by a law that would regulate common carriers. The parent, the consumer and the public must do their share in a suppression of the evil.

I am pleased to announce, and I speak advisedly, when I say there has been a decrease in child labor in Illinois in the past three years to the extent of eighty per cent. This gratifying result is due to the enforcement of the new child labor law which was enacted in 1903; to the policy of individual inspection; to tempering the enforcement of the law with a campaign of education among employers, giving them an opportunity to be heard before they are prosecuted for alleged violation of the law; and to the policy of the state factory inspector's office in enforcing a measure that was enacted in the name of humanity and at the request of all creeds.

I believe in prosecution where moral suasion fails. Where repeated carelessness among employers caused technical violations of the law, the offenders have been prosecuted with good results. Prior to 1903 our factory inspectors were handicapped by inadequate legislation. One of the great evils that caused so much child labor in Illinois previous to 1903 was a law which exists to-day in a number of other states, viz.: "The issuance of certificate merely upon the affidavit of the parent or guardian." This pernicious system merely places a premium upon child labor and perjury. Out of one hundred test cases in Chicago in 1902, it was found that eightytwo of the children involved were so small in stature, as to arouse the suspicion of factory inspectors, who investigated the baptismal and birth records of these children, and ascertained that they were only eleven, twelve and thirteen years of age, notwithstanding the fact that they had gone to work on certificates issued by notaries public, and sworn to by their parents, attesting that these children were fourteen years of age. Based upon these test cases, it was estimated, at that time, that out of 15,000 children employed in Cook County on affidavits 3,000 were under fourteen years of age, the legal age limit to go to work. The false affidavit system which exists to-day in many of the states in a large measure contributes to the employment of children under the legal working age, aided and abetted by parents, who place commercialism above conscience, and by the notary public, who is guided by the spirit of greed to get his fee at the sacrifice of the future welfare of the child. In 
view of the fact that these test cases in Chicago in 1902, demonstrated that one out of five children who were then employed was under fourteen years of age, it is logical to deduct, without fear of successful denial, that where a child labor law does not require absolute proof of age such legislation in every state is responsible, to a great degree, for the federal census returns, showing the employment of so many children under fourteen years of age. Doubtless the parents gave the child's correct age to the census enumerator, and then perjured themselves to the notary public, or the official who issued the working certificate.

Another defect in the old child labor law of Illinois-which exists to-day elsewhere-was the lack of requirement for an educational test before the child was eligible for employment. This merely encourages illiteracy. It is a menace to the future productive value of the child, and will be an inevitable contributor to delinquency or dependency in youth, and eventually the prison or the poorhouse when that child's life ripens into maturity. Usefulness and success in civic and industrial life depends upon the fundamental principles of health and education; upon the moral and intellectual advancement of childhood, and proper mental and physical equipment for the occupational life.

Under the old statutes of Illinois there was not sufficient protection to children in hazardous employment, in those vocations that jeopardized health, life and limb. This inadvertence, which Illinois has remedied, still exists in other states to-day, with the exception of Ohio. Nothing so appeals to the sympathy of human kind as the child on the crutch, or the child whose life has been deformed, and its vitality sapped as a result of the shortsighted policy of careless employers, who permitted the child to be employed at a dangerous or injurious occupation before that child was old enough to exercise proper discretion for personal safety. The result has been, the child was crippled for life.

Under the old law in our state, small children were employed in industrial plants, flitting like little shadows of the night in the domain of an industrialism, that even defied the laws of nature. While thousands of more fortunate children were at home in bed, many of the victims of child labor worked all night in the glass works, withering their young lives away before the hot glare of the furnaces. Humanity demanded, and humanity obtained, a clause in 
the new law, which provides that children between the ages of fourteen and sixteen cannot work between the hours of 7 p. $\mathrm{m}$. and 7 a. $\mathrm{m}$. It also demanded that if eight hours was long enough for a man to work, it was long enough for a child to work. As a result, improved legislation regulating and restricting the hours of employment of children in Illinois has been of great value to the health of thousands of children employed in manufacturing, mercantile and other pursuits.

The eight-hour clause of our law applies to every day and month in the year. Some states make an exception for the busy season. Childhood should be protected at all seasons-particularly during the rush incident to the Christmas holidays-in department stores and in other places of employment, where increased activity places an extra burden of long hours upon the shoulders of tired and overworked childhood.

The Illinois statute of to-day provides that no child under fourteen years of age shall receive a certificate to go to work, and that no child between fourteen and sixteen shall receive a certificate to do so, unless said child can read and write simple sentences. The system of issuing certificates safeguards proof of age and requires this educational test. It further provides for an initiatory certificate, to be obtained from the principal of the school the child last attended, which it presents to the superintendent of public or parochial schools, who then issues the age and school certificate, or permit, upon which the child goes to work. As evidence of the fact that many children enter industrial life before they have completed an elementary education, the official records show that from July, 1903, to the close of $1905,30,643$ working certificates were issued in Chicago by the superintendent of public schools, and that of this number only 6,60I pupils had finished eighth grade, and 16,199 had not reached seventh grade.

As evidence of the great value of co-operation between compulsory education and child labor laws, the enactment of a new compulsory education law in Illinois at the same time that a new child labor law was passed in 1903, made it possible for factory inspectors and truant officers to co-operate in the successful promotion of attendance at both the public and parochial schools. The school enrolment and average daily membership in Chicago-par- 
ticularly in the elementary grades-have been greatly improved within the past three years. The average annual truancy absences in Chicago, including repetitions, one year prior to the enactment and enforcement of the child labor and compulsory education laws, were $7,53^{6}$; one year after these laws went into effect these truancies were decreased to 5,673 , or a reduction of nearly 2,000 truancies within the period of one year. And in addition to checking truancy, there was an increase at the public schools, according to Superintendent E. G. Cooley, of some 8,000 pupils above the natural increase in population. There was also an increase in the parochial schools, notably in St. Stanislaus Parish, where it became necessary to build an additional parochial school, to accommodate the demand for seats. This parish is in the heart of one of the cosmopolitan centers of Chicago, in which the Polish nationality predominates, and among a class of children, many of whose parents formerly adhered to the theory of the productive instead of the educative.

There has also been a reduction in the employment of children in the Chicago sweatshops from $14 \frac{1}{2}$ per cent to 9 per cent. The percentage of children employed in Illinois, in I893, was 8.2 per cent; the present percentage has been reduced to $\mathrm{I} .5$ per cent. When we consider that the Illinois inspectors cover every possible kind of an industrial or mercantile plant, store, or shop, mine or factory, this is the lowest reported percentage of child labor of any state in the Union. In 1893 , out of every thousand wage-earners employed in mercantile and industrial establishments, eighty-two were children between the ages of fourteen and sixteen. In I905 this ratio was reduced to fifteen children of every thousand persons employed.

Child labor has been driven from the coal mines of Illinois. This was accomplished by my interpretation of the clause of the law governing hazardous employment-an interpretation that was combatted by the coal operators' association. A test case was subsequently brought in the courts, in which I was sustained, and as a result 2,200 children were emancipated from a life of underground servitude. Consequently, to-day no child under the age of sixteen can work in a coal mine in Illinois.

These results could not have been achieved if our efforts had been confined to moral suasion. Persuasion is a divine and beautiful 
thing, but the enforced law, with a penalty attached, is more effective.

During the year ending December, I905-the latest obtainable for comparative statistics-we prosecuted and secured convictions of 53I defendants on 994 counts. The vigilance of inspectors, backed by the firm policy of the department in prosecuting offenders, has been the greatest factor in the reduction and gradual elimination of child labor in Illinois.

When the law was first enacted, the department, realizing that enforcement should be tempered with fairness, distributed 72,000 copies of the law to educate employers throughout the state, and thus the industrial and mercantile public was fully advised of the requirements of the new statute. This action was prolific of good results. It proved a source of much value, not only to employers, but to school authorities, the press, and the labor and public-spirited organizations interested in an enactment that was for the immeasurable good of the commonwealth.

It is the policy and the system of the Illinois state factory inspector's department, to inspect industrial and mercantile establishments in every town and city, of a thousand population and over. The work covers every store, office, laundry, mercantile establishment, theatre, concert hall, place of amusement, factory and workshop in each town and city visited. The inspectors question individually each child employed. They record all suspects. They call upon the public and parochial school authorities and ascertain the true age of all such suspected children, and obtain from the school authorities the names and addresses of all children who deserted the school for the factory without having obtained from the school authorities a proper permit.

We have women as well as men inspectors. We also maintain a night inspection as well as day inspection, recording all inspections made, so that we may be guided in properly disposing of any violations found on a future visit. School authorities are required by the statutes to report to us all violations coming to their attention. All complaints-from all sources-are acknowledged and investigated, and the complainant informed as to the results of the investigation. This system required the inspection in the last year of over 70,000 places, representing 264 towns. All children under the 
age of fourteen found employed are reported to the school authorities.

In Illinois we believe in a spirit of co-operation between the factory inspector, the truant officer, the teacher, the social settlement worker, the probation officer, the club woman, and all humanitarians who are soldiers in the common cause of battling for the protection and the advancement of child life. Unity of effort among childhelping agencies and representatives of every creed, and every organization interested in childhood was responsible for the victory in the legislature that gave us our new child labor law, in spite of the powerful opposition of corporations that opposed it. We believe that the repression of child labor and the necessity of compulsory education are essential for the good of the community, for the good of future citizenship, for the safety of society and the destiny of the republic. The spirit that demands the emancipation of children from industrial slavery is but natural in the state that Lincoln loved.

Particularly do we realize the fact that if factory inspectors exclude a child from employment in a factory or workshop, that child should not be permitted to run at large upon the streets, for it is upon the street that evil associations corrupt childhood. For that reason the return of the child by the truant officer is a factor in insuring an intellectual future after the child has been dismissed from employment.

We are in need, however, of additional legislation in Illinois, that will compel a child, after having reached the age of fourteen, to either go to work or continue at school, after it has attained this maximum of the compulsory attendance age. A child between the ages of fourteen and sixteen should not be permitted to waste these two valuable years of its life in idleness that will inevitably contribute to crime in the future. It is from juvenile delinquency that adult crime receives so many recruits.

The census figures of 1900 , relative to the number of children employed at gainful occupations in Illinois, do not apply to present conditions, as the census was taken six years ago.

It must be realized that Illinois is a great agricultural state, and that many children between the ages of ten and fifteen were employed on farms at certain periods of the year. In the urban life, most particularly in Chicago, many children sell newspapers 
after school hours, and are exempt under the child labor law. It is to be remarked in the passing that the school records show that thousands of children, some of whom formerly worked in the factories under the old affidavit system, were taken from their places of employment and placed in school in 1903-04. The question of the employment of children under fourteen years of age does not apply in any marked degree to present conditions in Illinois. It must also be remembered that the census enumerators quite likely included in their estimate of females between ten and fourteen years of age, a number of girls who were engaged in domestic service in the home, as well as boys who assisted on the farm. At the time the census was taken there were doubtless thousands of children employed in the coal mines of the state. This evil has since been eradicated by the decision of the courts, which makes it impossible for a child under sixteen to work in a coal mine.

The latest available statistics of the number of children employed at gainful occupations are in the annual report of the Illinois state factory inspector for the year 1905, which shows the results of inspection in 70,539 industrial and mercantile plants, stores and offices, and other places where children were employed. The number of children under sixteen years of age employed in these 70,539 places in the state, in 1905 , was $I I, 75^{2}$, compared to 19,839 in 17,209 places inspected in Igor. These figures do not apply to agricultural pursuits, or street trades, or domestic service.

Our problem in Illinois, therefore, is confined largely to the regulation, protection and hours of employment of children between the ages of fourteen and sixteen. The new child labor law absolutely prohibits the employment of children under fourteen at any time of the year in any store, office, laundry, mercantile institution, factory or workshop, etc., or in any other occupation during the period that the schools are in session.

The present procedure of proving age by methods other than the mere statement of the parent, practically abolishes the employment of children under fourteen. Therefore it will be seen that the former conditions in Illinois, that prevailed in I900, and which were made possible by a lax law and a lax method of inspection of only I4,2 I9 plants in that year, have been supplanted by improved legislation, that is both stringent and effective; by an increased activity 
of inspectors, that has made it possible to cover 70,539 plants in I905, and to show a decrease in child labor between fourteen and sixteen years of age from 3.3 per cent in 1900 , when the census was taken, to I.5 per cent in 1905 .

The new compulsory education law of Illinois now compels children in the country districts-between the ages of seven and fourteen-to attend school the entire time the school is in session. The minimum period in the country districts is I Io days of actual teaching, and the period in the city districts is forty weeks, or the full school year.

In Chicago there is a great cosmopolitan population. Of the parents who send their children to work only 20 per cent of these parents are of American birth. About 23 per cent are born in Germany; I2 per cent in Bohemia; Io per cent in Sweden, Norway and Denmark; 8 per cent in Russia; 8 per cent in Ireland; 5 per cent in Italy; 4 per cent in Poland, and the remaining Io per cent from the other countries of Europe. About 20 per cent of the children go to work within one month after they are fourteen years of age, and 4o per cent within four months thereafter. This shows a tendency on the part of many parents to send their children to work as soon as they have completed the compulsory school attendance age, at fourteen. Many of these parents have a limited knowledge of English, and quite a number of them cannot read or write. From a physical standpoint, the children of American-born parents appear to be in the best condition. The Polish children are poorly developed in chest measurement and are stunted in growth. The Italian and Russian children are usually short in stature. It seems to be the perversity of fate that in large families the revenue is small, and the lack of socialization of the parents and their poverty in life is due to their own deficiency of education. Hence, were it not for legislation in Illinois, that requires compulsory school attendance, these children would receive the unfortunate heritage of an illiterate and indifferent parenthood.

It has always been the apology of the south, for the prevalence of child labor, that it was a charitable impulse to put children to work who were the products of the impoverished home, and who came from large families, where the combined earnings of children were necessary to assist in the support of the parents. It is, there- 
fore, apparent that the conditions in Chicago, in the colonies of the foreign-born population, made possible by our present lax immigration laws, present the same excuse, because it was the custom of the parents abroad to send children to work at a premature age. But the Illinois law inculcates the American principle into the hearts of these immigrants, with the result that they are compelled to send their children to school until they are fourteen years of age. Hence the children are not a menace to the wage scale of the adult, and we work parents more and children less. We must not blame the south alone for the prevalence of child labor in its mills, so long as northern capital operates these mills and is deaf to the cry of the children.

The ideal child labor law does not exist. But I believe the present statute of our state is one of the best and in advance of any so far enacted by our legislatures. It can be further improved, however, by imposing increased authority upon a factory inspector, to demand, wherever necessary, a certificate from a physician of good repute, showing that the child in question is physically able to perform all of the duties required of it, and that the employment of said child will not imperil its health. It should also be amended to state specifically that the child should be able to read and write in the English language, and to pass a reasonable educational test in that language, instead of being accepted for employment on the present limited educational test of reading and writing simple sentences in any language.

There should also be provisions to regulate the street trades, such as newsboys, venders, etc., and an amendmient to protect girls between the ages of sixteen and eighteen, and to prevent their employment at night, or the employment of any girl or boy between these ages in any concert hall or place of amusement where intoxicating liquors are sold.

The boys and girls of this day and generation represent the fathers and mothers of the future. If child labor is permitted to increase; if we do not throw safeguards about the children of today, to protect their health, their morals and their education, the question of this republic will not only be one of race suicide, but race decay, that will result in this country losing the laurels which it now possesses, as the most enlightened and progressive in the world. 
Our flag waves a welcome to the oppressed on foreign shores. But the immigrant must be impressed when he comes from the fatherland of Europe, that this is America, and that the precious trinity of our national life is the home, the school, and good citizenship. Upon these tenets a great country has risen to stand supreme among the nations of the earth, with fidelity and protection for its children, as well as the stability of its people and the purity of its homes.

And we should say unto capital at home, "Do not permit the competitive life to build up our industrial institutions upon the vitality of little children, or permit the factory to rob the school of that rising generation, upon whose shoulders rests the future and the fate of this republic. 